\title{
Every little helps
}

Novel techniques that could help to make human embryonic stem-cell research morally acceptable will not immediately defuse the ethical debate over the work.

\rceil his week, Nature is publishing online two papers describing new techniques for deriving embryonic stem cells. The limits on federal funding for human embryonic stem-cell research in the United States have inspired political lobbying and led to the creation of alternative funding sources and international networks to facilitate offshore collaborations. These papers mark a new approach: they are aimed at making human embryonic stem-cell research morally acceptable (see page 1076 ).

One group, from the Massachusetts-based biotechnology company Advanced Cell Technology, has used a single-cell biopsy procedure, similar to an in vitro fertilization (IVF) technique called preimplantation genetic diagnosis (PGD), to derive mouse stem cells without affecting the subsequent development of the donor embryo (Y. Chung et al. Nature doi: $10.1038 /$ nature $04277 ; 2005)$. The authors propose that human embryonic stem-cell lines could be created in the same way, using embryos that are already undergoing the IVF technique as donors, so there is minimal additional risk to the embryo.

One limitation of this method is that stem cells derived in this way would represent a limited gene pool restricted to the clientele of IVF dinics, who tend to be affluent and white. But a second method, reported this week by researchers at the Whitehead Institute, also in Massachusetts, would produce cells matched to any donor.

The altered nuclear transfer (ANT) method, which has been tested in mice, switches off a gene in the donor nucleus before it is transferred to the egg (A. Meissner \& R. Jaenisch Nature doi:10.1038/ nature $04257 ; 2005)$. The gene is necessary for the embryo to implant in the womb, so the embryo cannot develop beyond the implantation stage. William Hurlbut, a bioethicist at Stanford University in California and a member of the President's Council on Bioethics, argues that these embryos have neither the cellular organization nor the developmental potential of a normal embryo, and so need not be accorded the same moral status.
It remains to be seen if either method can do anything to resolve the political impasse over human embryonic stem-cell research. The PGD method was attacked in Congress earlier this year. Critics said that delaying the IVF procedure to allow one of the cells in an eightcell embryo, or blastomere, to divide into cells that can be used for both IVF and embryonic stem-cell culture exposes the embryo to more risk than normal. Geneticists and fertilization specialists must now decide whether the idea is worth testing in humans.

The ANT method, on the other hand, is predicated on the question of when life begins - a question that scientists can't answer and that non-scientists cannot agree on. Several Harvard scientists have argued that ANT would only make an already difficult procedure even more cumbersome, and delay progress on therapies (N. Engl. J. Med. 351,
"Now that the science has been reported, the advantages of both methods can be rigorously assessed." $2791-2792 ; 2004)$. Another question is whether there is a moral difference between making an embryo that is incapable of forming the tissue required for implantation, and stripping the tissue from the embryo after it has formed.

The ethical appeal of the approach has yet to be tested. If proponents such as Hurlbut are sufficiently numerous and influential, it could help to tip the balance towards a more benign regulatory and funding environment for human embryonic stem-cell research.

The scientific and ethical issues raised by these discoveries are complex, and by publishing these papers Nature is not endorsing either of them as a solution. Rather, we support the full funding of human embryonic stem-cell research using all available technologies, subject to tight ethical oversight. Now that the science has been reported, the advantages and disadvantages of both methods, as well as their feasibility in humans, can be rigorously assessed.

\section{An unhealthy practice}

\section{Prescription guidelines should not be written by people with financial conflicts of interest.}

\footnotetext{
$\Lambda$
} survey reported on page 1070 of this issue suggests that pharmaceutical companies often have financial links with the people who write guidelines on how physicians prescribe drugs. More than a third of the authors of such guidelines declared a financial connection to the companies that produced the drugs.

No one is suggesting that the authors in question are deliberately adjusting guidelines to match these interests: most of them surely have their patients' interests at heart. But that doesn't mean that the potential conflicts don't matter. In other areas of medicine - induding dinical trials and educational programmes - pharmaceutical money has been shown to exert a subtle influence on the choices made by physicians and researchers (see A. Wazana J. Am. Med. Assoc. $283,373-380 ; 2000$ ). So it is not unreasonable to assume that a similar effect is at work in the preparation of prescription guidelines.

Several simple steps could be taken to improve matters. The doctors' organizations that write most of the guidelines should require that authors fully disclose potential conflicts of interest and add their disclosure statements to the guidelines. This doesn't always happen now - despite widespread agreement that it's the right thing to do.

But disclosure is only a first step towards objectivity. The survey also revealed that about $10 \%$ of all guideline panels include an author who holds stock in a relevant company. These holdings should be 
restricted to modest levels, above which the authors should excuse themselves from writing guidelines. The professional societies that produce the guidelines should also consider introducing a ceiling on what authors can earn from relevant companies. Some organizations, such as the Institute for Clinical Systems Improvement, a Minnesota-based collaboration between US healthcare providers that produces advice on clinical practice, already have such criteria. There is no reason why others shouldn't follow suit.

But the time may also be ripe for a more radical overhaul of the system, particularly in the United States, where the financial stakes are highest and where the government currently plays almost no role. The organizations that produce the guidelines argue that it is impractical to exclude every individual with such a financial link from their preparation. But bodies in related spheres already do this. The Consensus Development Program at the National Institutes of Health, for example, which publishes advice on areas of clinical practice where there is debate about treatment options, operates a 'jury and witnesses' model, in which experts with financial links can only present evidence, not make judgements on it.

A similar mechanism could be set up at the US health department, for example, to steer the preparation of clinical guidelines. This would, of course, require modest public funding. Britain's National Institute for Health and Clinical Excellence, which receives government funding and devolves its decisions to external experts, provides a useful model.

But would such an organization be able to produce guidelines quickly enough? When a new drug becomes available, a team of physicians can review the evidence and make recom-
"A 'jury and witnesses' mechanism could be set up at the US health department to steer the preparation of guidelines." mendations in a few months. More sophisticated, consensus-based approaches typically take longer. But if it is adequately funded, such a body could produce guidelines expeditiously. If US physicians really want to separate marketing from medicine, they should support its creation.

\section{Grand ambition}

\section{Germany's coalition government is well placed to reform the country's scientific system.}

n most countries, the award of a Nobel prize is a cause of much self-congratulation. But not in Germany. When Theodor Hänsch won a share of this year's physics Nobel for his work on laserbased precision spectroscopy, many commentators saw the award as an exception to the rule of underperformance in German science.

Such introspection is all too characteristic of modern Germany. The truth is that German scientific prowess and inventiveness can still compete with the best in the world in many spheres. But the science system suffers from a number of structural weaknesses. The new government, almost certainly a 'grand coalition' of the two large political parties, the Social Democrats (SPD) and the Christian Democrats (CDU/CSU), should move quickly to address them. And the science ministry, which is likely to be led by Annette Schavan, a former minister for education in the state of Baden-Württemberg, should focus on areas where intervention is really needed.

It should start by revisiting Germany's restrictive rules and regulations in stem-cell research and plant biotechnology, which make it hard for researchers in Germany to be competitive. Former chancellor Gerhard Schröder had promised to open discussions on regulations that effectively prevent research using embryonic stem cells. Schavan said she wouldn't. This is one promise she should break.

Despite its long tradition in science, Germany still lacks research universities that can compete with the best in the United States and Britain. The federal education system, which distributes strong universities all over Germany, has served the country well. But to compete internationally, Germany needs to target a few institutions and support them to the hilt. The previous government launched a $€ 1.9$-billion (US\$2.3-billion) programme to strengthen the research profile of the best German universities. The new government will need to push this programme hard if it is to overcome state rivalries and allow the strongest research universities to grow stronger.

Across the university system as a whole, reforms are needed to ensure that appointments are made on merit. At present, political considerations and personal influence are often more important than a candidate's scientific strengths. If institute and department heads, and not ministry officials, were solely responsible for making appointments, this situation would change. Schavan says she wants the federal government to retreat from its joint responsibility for universities, and this could prove to be beneficial provided that the state (Länder) governments grant increased autonomy to the universities afterwards, as many of them have pledged to do.

Given a longer leash, universities could work harder to attract the best scientists from abroad. Germany has failed to make the most of the scientific talent in eastern Europe, despite its geographical proximity. While US universities rolled out the red carpet to immigrant scientists from that region, most German universities have not been flexible enough to create new positions, or to offer competitive salaries and conditions. The new government must help to put that right.

It should also take steps to
"The new government should work to create conditions that will keep women in research." make research careers more attractive for the dedining number of science students in Germany itself, and should create conditions that will keep women in research. It can start by nurturing merit-based appointments and providing incentives for employers to provide decent child care (see Nature 437, 296; 2005). Schavan, who calls herself a 'conservative feminist,' and Angela Merkel, the chancellordesignate and a former physicist, need to find ways to help more women achieve in science what they have done in politics.

Finally, money counts. Scientists will expect both coalition partners to stick to their pre-election commitments to gradually increase public science and education budgets. This also has a European dimension: it is unlikely, without Germany's active support, that the European Union's next Framework research programme will develop as it should. 